FOLIA HISTORICA CRACOVIENSIA, 21: 2015, s. 265-287

DOI: http://dx.doi.org/10.15633/fhc. 1738

Joanna Małocha

Uniwersytet Papieski Jana PawŁa iI w Krakowie

\title{
Święta Eulalia z Meridy \\ i rozwój jej kultu \\ w świetle średniowiecznych \\ utworów poetyckich
}

Kult męczenników, sięgający pierwszych wieków Kościoła, w średniowieczu stał się jednym z najbardziej charakterystycznych przejawów pobożności chrześcijańskiej. Jednakże jako zrodzony wśród mas ludowych został uznany, uregulowany $\mathrm{i}$ - tylko w pewnej mierze - dostosowany przez władze kościelne do obowiązujących zasad. Wyrażał on pragnienie posiadania orędowników, którzy w swej szczęśliwej nieśmiertelności przebywają blisko Boga, a jednocześnie - w swych grobach i relikwiach - są bezpośrednio dostępni ziemskim braciom $\mathrm{w}$ wierze ${ }^{1}$.

Obiektem takiej właśnie czci była również św. Eulalia z Meridy - dawniej jedna $\mathrm{z}$ bardziej znanych męczennic hiszpańskich z okresu prześladowań cesarza Dioklecjana, a dziś postać niemal zapomniana. Ze schyłku starożytności oraz wieków średnich zachowała się jednak część materialnych świadectw jej kultu. Przy czym są to zarówno źródła pisane (pasje, poematy, adnotacje w działach

${ }^{1}$ Zob. P. Allard, Dix leçons sur le martyre, Paris 1905; P. Brown, The Cult of the Saints. Its Rise and Function in Latin Christianity, Chicago 1980; S. Longosz, Niektóre aspekty teologii męczeństwa w literaturze wczesnochrześcijańskiej, „Tarnowskie Studia Teologiczne” 7 (1979), s. 49-73; H. Misztal, Męczeństwo - najwyższa forma miłości - w orzecznictwie Kościoła, [w:] In Christo Redemptore. Księga pamiątkowa ku czci Księdza Profesora Jerzego Misiurka, red. J. Popławski, Lublin 2001, s. 219-237; J. Ptaśnik, Kultura wieków średnich. Życie religijne i społeczne, Warszawa 1959, s. 73-75; M. Simon, Cywilizacja wczesnego chrześcijaństwa I-IV wieku, Warszawa 1981, s. 301; M. Starowieyski, Męczeństwo, [w:] Męczennicy, red. E. Wipszycka, M. Starowieyski, Kraków 1991, s. 84-142; Męczennicy w świecie późnego antyku, red. B. Iwaszkiewicz-Wronikowska, D. Próchniak, Lublin 2004. 
kronikarskich i martyrologiach, kazania oraz oficja brewiarzowe $)^{2}$, jak i niepisane (przedstawienia mozaikowe i malarskie, zabytki epigrafiki) ${ }^{3}$.

${ }^{2}$ Znane są cztery wersje pasji św. Eulalii, datowane na okres od IV do Ix wieku i oznaczane umownymi skrótami EM, EB1, EB2 oraz EB3. Męczennicy tej poświęcił także trzeci hymn ze zbioru Peristephanon wybitny poeta starożytnego chrześcijaństwa łacińskiego Aureliusz Prudencjusz Klemens. Wzmianki na jej temat znaleźć można ponadto w historiograficznych działach In gloria Martyrum Grzegorza z Tours, Historia de Regibus Gothorum, Wandalorum et Suevorum Izydora z Sewilli oraz w kronice Hydacjusza. Zob. Aureliusz Prudencjusz Klemens, Wieńce męczeńskie (Peristephanon), oprac. M. Starowieyski, Kraków 2006, s. 183-197; Bibliotheca Hagiographica Latina Antiquae et Mediae Aetatis adiderunt Socii Bollandiani, t. 1, Bruxellis 1989-1899, nr 2693, 2694, 2696, 2700, s. 405; Georgius Florentius Gregorius Turonienisis, De gloria beatorum Martyrum, [w:] S. Georgii Florentini Gregorii Turoniensis episcopi opera omnia, Patrologiae cursus completus sive bibliotheca universalis, integra, uniformis, commoda, oeconomica omnium ss. Patrum, Doctorum Scriptorumque ecclesiasticorum, qui ab aevo apostolico ad usque Innocentii III (anno 1216) pro Latinis et concilii Florentini (ann. 1439) pro Graecis floruerunt. Series Latina [dalej: PL], t. 71, accurante J.-P. Migne, Parisiis 1870, kol. 785; Isidorus, Historia de Regibus Gothorum, Wandalorum et Suevorum, [w:] Sancti Isidori Hispalensis episcopi opera omnia, t. 5-7, PL, t. 83, Parisiis 1862, kol. 1066. Znaczną grupę stanowią także teksty bezpośrednio związane z liturgicznymi obchodami kultu męczennicy. Przy czym znane współcześnie średniowieczne teksty mszy oraz oficja brewiarzowe ku czci św. Eulalii przynależą do rytu mozarabskiego. Zaś dłuższe lub krótsze adnotacje na jej temat odnajdujemy w kolejnych ważniejszych martyrologiach zachodnioeuropejskich z tego okresu od Martyrologium Hieronima poczynając, przez martyrologia historyczne Bedy Czcigodnego, Florusa, Anonima z Lyonu, Hrabana Maura, Adona z Vienne i Usuarda, a na Notkerze Balbulusie kończąc. Zachowała się także mowa na dzień wspomnienia hiszpańskiej świętej, autorstwa św. Augustyna. Zob. Agustin, Sermo cCCXIIIG [313 G]. De die Sanctae Eulaliae, [w:] Obras Completas de San Agustin, t. 15: Sermones, cz. 5: Sermones sobre los mártires (273-338), Madrid 1984, s. 587-589; Beda Venerabilis, Historia ecclesiastica, [w:] Venerabilis Bedae Anglo-Saxonis presbyteri opera omnia, t. 6, PL, t. 95, Parisiis 1863, kol. 21; Edition pratique des Martyrologes de Bede, de l'Anonyme Lyonnais et de Florus, red. J. Dubois, G. Renaud, Paris 1976, s. 33, 221; Le Martyrologe d'Adon. Ses deux familles. Ses trois recensions. Texte et commentaire, éd. J. Dubois, G. Renaud, Paris 1984, s. 84, 411-412; Le Martyrologe d'Usuard, éd. J. Dubois, Paris 1965, s. 179, 356; Liturgia Mozarabica secundum regulam beati Isidori. Missale mixtum. Praefatione, notis et appendicibus. Breviarium Gothicum, t. 1, PL, t. 85, Parisiis 1862, kol. 163-170, 707-714; Liturgia Mozarabica secundum regulam beati Isidori. Missale mixtum. Praefatione, notis et appendicibus. Breviarium Gothicum, t. 2, PL, t. 86, Parisiis 1891, kol. 1099-1102, 1273-1285; Notker Balbulus, Martyrologium per anni circulum, [w:] Remigii monachi S. Germani Antissiodorensis beati Notkeri Balbuli, S. Galli monachi opera omnia, t. 1, PL, t. 131, Parisiis 1884, kol. 1045; Raban Maurus, Martyrologium, [w:] B. Rabani Mauri Fuldensis abbatis archiepiscopi opera omnia, t. 4, PL, t. 110, Parisiis 1864, kol. 1185.

${ }^{3}$ Przede wszystkim chodzi tu o wizerunek św. Eulalii na mozaikowym przedstawieniu pochodu męczennic z bazyliki S. Apollinare Nuovo w Rawennie. Niemały jest także zbiór znaczenie już późniejszych dzieł sztuki malarskiej, które odwołują się do historii hiszpańskiej męczennicy. Grupę tę tworzą: fresk ścienny z kościoła S. Cristo de la Luz w Toledo (xII w.), miniatura z Pasjonału Stuttgarckiego (xıII w.), retabulum z katedry w Palma de Majorka (xIv w.), miniatura z Brewiarza Marcina Aragońskiego (xv w.), barceloński obraz „Madonna dei Consiglieri” Luisa 
Paradoksalnie jednak pomimo istnienia licznych dawnych świadectw popularności św. Eulalii - a może właśnie za sprawą ich wielości i zróżnicowania hagiografia staje dziś przed problemem teoretycznego istnienia dwóch świętych z IV wieku o tym samym imieniu i bardzo podobnej biografii. Jedni bowiem czczą Eulalię z Meridy, a drudzy jej imienniczkę z Barcelony, która jednakże pojawia się w źródłach z ponad trzechsetletnim „opóźnieniem”. Dopiero bowiem około 653 roku barceloński opat-biskup Quiricus ogłosił odnalezienie grobu miejscowej męczennicy i napisał ku jej czci hymn, tekst mszy oraz Akta. Kwestia rzeczywistej egzystencji obu bohaterek stanowi przedmiot żywej dyskusji historyków Kościoła i patrologów, nie jest jednak przedmiotem rozważań przedstawionych w niniejszej publikacji ${ }^{4}$.

Prezentowany artykuł $\mathrm{z}$ racji ograniczeń formalnych skupia się na analizie średniowiecznych utworów poetyckich, które w całości lub w części poświęcone zostały postaci św. Eulalii. Jak dotąd zarówno w rodzimej, jak i w zagranicznej literaturze przedmiotu - z przyczyn oczywistych głównie hiszpańskiej - brak jest tego typu sumarycznego zestawienia, zaś rozważane teksty nie doczekały się jeszcze tłumaczenia na język polski ${ }^{5}$.

Dalmau (xv w.), pizańskie retabulum ołtarzowe autorstwa Bicci di Lorenzo (xv w.), retabulum pędzla Pedro Berruguete z kościoła Wszystkich Świętych w Paredes de Navas (xv w.), obraz Pedro Serry z kaplicy Drogi Krzyżowej przy katedrze w Segorbe (xv w.), a wreszcie dzieło Johna Williama Waterhouse’a z 1885 roku. Natomiast do zabytków rzeźby związanych z kultem św. Eulalii zaliczyć można: srebrny relikwiarz z katedry w Oviedo (xII w.), alabastrową szkatułkę na relikwie świętej z katedry barcelońskiej (xIV w.), rzeźbę na filarze krużgankowym z hiszpańskiego klasztoru w Elna (XIV w.), reliefowe przedstawienia męczeństwa bohaterki ze ściany chóru katedry w Barcelonie (xvi w.) oraz miedzioryt F. Sigista z Xvin wieku. Zob. J. Boberg, Eulalia von Mérida (von Barcelona) Jungfrau, Mart. 10.12, [w:] Lexikon der christlichen Ikonographie, Bd. 6, Freiburg 1974, kol. 179-180; K. Künstle, Ikonographie der christlichen Kunst, Bd. 2: Ikonographie der heiligen, Breisgau 1926, s. 217; L. Réau, Iconographie de l'art chrétien, t. 3: Iconographie des Saints, part 1, Paris 1958, s. 463; W. Tünde, Painting in medieval Spain, Budapest 1981, s. 32.

${ }^{4}$ Zob. A. Fàbrega-Grau, Eulalie de Barcelone (Sainte), [w:] Dictionnaire d'Histoire et de Geographie ecclesiastiques, t. 15, éd. A. Baudrillart, Paris 1963, kol. 1381-1382; V. Saxer, Eulalia di Barcellona, [w:] Dizionario patristico e di antichità Cristiani, vol. 1, a cura di A. Di Berardino, Roma 1983, kol. 1279.

${ }^{5} \mathrm{~W}$ większości bowiem badacze skupiali się na wzmiankowanym już problemie liczby faktycznie istniejących męczennic o imieniu Eulalia. A co za tym idzie przeprowadzali oni skrupulatną selekcję materiału, przywołując w swych rozważaniach jedynie wybrane źródła i to tylko o tyle, o ile przydatne były w popieraniu lub negowaniu kolejnych hipotez. Zob. A. Fàbrega-Grau, Santa Eulalia de Barcelona: revision de un problema historico, Rome 1958; Z. Garciá-Villada, El problema de las dos santas Eulalias. „Razón y Fe” 68 (1920), s. 166-186; Z. Garciá-Villada, Historia ecclesiástica de España, t. 1, part 1, Madrid 1929, s. 282-300; H. Leclercq, Eulalie de Mérida et de Barcelone (les Saintes), [w:] Dictionnaire d'archeologie chretienne et de liturgie, t. 5, part 1, 


\section{Dzieje św. Eulalii w świetle tradycji}

Według tradycji św. Eulalia przyszła na świat około 292 roku w hiszpańskiej Meridzie (Emerita Augusta), jako córka powszechnie szanowanych i zamożnych rodziców. Już od najmłodszych lat miała ona stronić od swawolnej zabawy oraz wykazywać skłonność do modlitewnej zadumy i kontemplacji ${ }^{6}$. W chwili zaś wprowadzenia $\mathrm{w}$ życie na terenie Luzytanii antychrześcijańskich edyktów Dioklecjana Eulalia zapragnęła poświęcić swe młode życie za wiarę. Pomimo wysiłków rodziców, którzy ukryli córkę w podmiejskiej posiadłości, w 304 roku dziewczyna zdołała uciec i stanąć przed obliczem namiestnika Kalpurninusa ${ }^{7}$. Miał on wówczas usłyszeć z jej ust gorzkie wyrzuty i harde odpowiedzi, a część źródeł przypisuje nawet przyszłej męczennicy śmiały czyn oplucia urzędnika i podeptania pogańskiego idola ${ }^{8}$. Wobec tego, iż żadne namowy ani groźby nie zdołały zmusić Eulalii do złożenia wymaganej ofiary, sędzia skazał ją na męki i śmierć. Źródła nie są zgodne co do tortur, jakim została poddana. Najczęściej jednak wymienia się tu chłostę, rozdzieranie ciała żelaznymi hakami, polewanie głowy wrzącym olejem i ołowiem, sypanie soli na rany, wreszcie przypalanie

éd. F. Cabrol, H. Leclercq, Paris 1922, kol. 705-732; H. Moretus, Les deux Eulalies. „Revue des questions" 117 (1911), s. 85-111; A. F. Negri, M. Sotomayor, Eulalia, santa, martire in Spagna, [w:] Bibliotheca Sanctorum, t. 5, a cura di F. Caraffa, Roma 1964, kol. 208; Acta Sanctorum. Novembris, t. 2, ed. H. Delehaye, P. Peeters, M. Coens, Bruxellis 1931, s. 89-9o. Natomiast na polskim gruncie naukowym wymienić należy lapidarne artykuły ks. H. Frosa w Martyrologium, czyli wspomnienia świętych przypadające na poszczególne dni roku, Warszawa 1984 oraz Wspomnienie świętych na każdy dzień roku. Martyrologium, Kraków 1992; a także: H. Fros, F. Sowa, Twoje imię. Przewodnik onomastyczno-hagiograficzny, Kraków 1975; H. Fros, F. Sowa, Księga imion i świętych, t. 2, Kraków 1997.

${ }^{6}$ Krótkie wzmianki o rodzinie i dzieciństwie świętej oraz jej cechach, przystających zresztą do obowiązującego w hagiografii średniowiecza rysu charakterologicznego przyszłej męczennicy, zawierają m.in.: J. Baudot, P. Chaussin, Vies des Saints et des Bienheureux selon lordre du calendrier avec l'histoire des fêtes, t. 2: Février, Paris 1936, s. 277; J. [T. Jagodziński], Eulalja, święta, panna i męczen., [w:] Encyklopedija kościelna, t. 5, red. M. Nowodworski, Warszawa 1874, s. 108.

7 Imię tegoż urzędnika rzymskiego bardzo rzadko jest podawane przez badaczy, wymienia je np.: Ph. Seeböck, Kleine illustrierte Heiligen-Legende, Einsiedeln 1886, s. 749.

${ }^{8}$ Zob. R. Cammilleri, Wielka księga Świętych Patronów, tłum. M. Radomska, Kielce 2002, s. 188; J. Charkiewicz, Święte niewiasty. Mały leksykon hagiograficzny, Hajnówka 2001, s. 159; D. H. Farmer, The Oxford Dictionnary of Saints, New York 1992, s. 169; H. Leclercq, Eulalie de Mérida et de Barcelone..., dz. cyt., kol. 709; A. Marej, Evlaliâ Merisdkaâ (Eulalia Emeritensis), sv, [w:] Katoličeskâ̂ enciklopediâ, t. 1, Moskva 2002, kol. 1755; A. F. Negri, M. Sotomayor, Eulalia, Santa..., dz. cyt., kol. 208. Powyższe publikacje krótko opisują te wydarzenia, tłumacząc jednocześnie porywcze zachowanie św. Eulalii jej młodym wiekiem oraz gorącym pragnieniem męczeństwa. 
pochodniami. W czasie tej ostatniej męki włosy dziewczynki zajęły się ogniem, a ona sama wkrótce spłonęła. Według innej wersji - jako, że ogień nie czynił jej szkody - została ścięta mieczem ${ }^{9}$.

W momencie śmierci $\mathrm{z}$ ciała męczennicy miała ulecieć gołębica - popularny w hagiografii starożytnej i średniowiecznej symbol duszy zbawionej, wznoszącej się do nieba. Ponieważ zaś namiestnik nakazał pozostawić obnażone ciało świętej przez trzy dni na placu niepogrzebane, cudowny opad śniegu ukrył je przed wzrokiem pogan ${ }^{10}$. Ostatecznie wierni z Meridy pochowali Eulalię z należnym szacunkiem niedaleko miejsca jej śmierci, gdzie też wkrótce - wobec ustania prześladowań - wznieśli bazylikę ${ }^{11}$. Męczennica uznawana jest za patronkę żeglarzy, chorych na czerwonkę, torturowanych dzieci, uciekinierów oraz miast

${ }^{9}$ Zob. D. Attwater, The penguin dictionary of Saints, Harmondsworth 1982, s. 120; Z. Bauer, A. Leszkiewicz, Wielka księga świętych, t. 1, Kraków 2003, s. 188; V. Saxer, Eulalia di Mérida, [w:] Dizionario patristico e di antichità cristiane, vol. 1, a cura di A. Di Berardino, Roma 1983, kol. 128o.

Obydwa te sposoby wykonywania kary śmierci, a zwłaszcza ścięcie, były najczęściej stosowanymi wobec chrześcijan prześladowanych na mocy edyktów Dioklecjana. Podkreślił to zresztą P. Allard, tłumacząc przy tym, iż sędziowie wybierali dekapitację, nie tyle chcąc uszanować przywileje prawne i stanowisko społeczne osób skazanych, ile ze względu na szybkość wykonania takiego wyroku - chodziło im o jak najszybsze wytępienie chrześcijan. P. Allard, O męczeństwie, Warszawa 1914, s. 191. Niektórzy badacze wymieniają dodatkowo cuda, które towarzyszyły mękom świętej - między innymi kaci torturujący Eulalię płonącymi pochodniami mieli zostać obróceni w popiół. Zob. F. Giry, Vies des Saints d’après les Bollandistes, Surius, Ribadereira, t. 12, Paris 1867 , s. 463.

${ }^{10} \mathrm{O}$ znaczeniu gołębia jako symbolu niewinności i łagodności, a w ikonografii chrześcijańskiej także uosobieniu duszy opuszczającej po śmierci ciało męczennika zob. J. E. Cirlot, Słownik symboli, Kraków 2000, s. 140; D. Forstner, Świat symboliki chrześcijańskiej, Warszawa 1990, s. 232; R. Gilles, Le Symbolisme dans l'Art Religieux, Paris 1943, s. 27-28; W. Kopaliński, Słownik mitów i tradycji kultury, Warszawa 1985, s. 330; W. Kopaliński, Słownik symboli, Warszawa 1990, s. 100; M. Oesterreicher-Mollwo, Leksykon symboli 'Herdera', Warszawa 1992, s. 45; L. Réau, Iconographie de l'art chrétien..., dz. cyt., s. 463; V. Schauber, H. M. Schindler, Ilustrowany leksykon świętych, Kielce 2002, s. 173; M. Stafford, D. Wera, An illustrated dictionary of ornament, Hampshire 1974, s. 75 .

${ }^{11}$ Obiekt ten nie zachował się niestety do dnia dzisiejszego, jednakże próby choćby częściowego otworzenia wyglądu jego wnętrza dokonywane są na podstawie danych zawartych we wspominanym już hymnie III Peristephanon Prudencjusza. Zob. J. M. Fernández Catón, Manifestaciones ascéticas en la iglesia hispano-romana del siglo IV, León 1962, s. 147; G. Ferretto, Note storico-bibliografiche di archeologia cristiana, Città del Vaticano 1942, s. 426; I. Ortiz de Urbina, Eulalia, santa, martire, [w:] Enciclopedia cattolica, vol. 5, a cura di P. Paschini, Città del Vaticano 1950, kol. 806; M. Sotomayor y Muro, La Iglesia en la España Romana, [w:] Historia de la Iglesia en España, t. 1, dirigida por R. Garcia-Villoslada, Madrid 1979, s. 180, 280. 
Oviedo, Barcelony, Meridy i całej Katalonii ${ }^{12}$. Zaś we współczesnym kalendarzu liturgicznym wspomnienie św. Eulalii przypada na dzień 10 grudnia ${ }^{13}$.

\section{Średniowieczne utwory poetyckie związane z postacią św. Eulalii z Meridy}

Zbiór zachodnioeuropejskich średniowiecznych utworów poetyckich w całości lub choćby w części poświęconych postaci św. Eulalii z Meridy otwiera hymn De virginitate (O dziewictwie) Wenancjusza Fortunatusa (zm. 6o1). Dzieło to jest jednym z ponad trzystu znanych dzisiaj, a zebranych w jedenaście ksiąg, wierszy o tematyce religijnej i świeckiej autorstwa frankońskiego mistrza pióra ${ }^{14}$. Utwory owe odznaczają się wyraźnie na tle ogółu poezji okresu merowińskiego przez swą świeżość, autentyczne przeżycia oraz umiłowanie świata i przyrody. Dzięki temu też - mimo popełnianych lapsusów gramatycznych - Fortunatus uchodzi

${ }^{12}$ Spośród wymienionych wyżej patronatów praktycznie wszystkie wynikają z dziejów św. Eulalii, tego, kim była i jaką śmierć poniosła. Jedynie fakt, iż jej orędownictwa wzywają również żeglarze może budzić zdziwienie. Taki stan rzeczy próbuje się jednak wyjaśniać powszechną wśród mieszkańców Hiszpanii wiarą w cudowną moc wody, w której spoczywać miały przez długi czas relikwie męczennicy, a ściślej - jej czaszka. Zob. D. H. Kerler, Die Patronate der Heiligen. Ein Alphabetisches Nachschlagebuch für Kirchen-, Kultur-, Kunsthistoriker, sowie für den praktischen Gebrauch des Geistlichen von [...], Ulm 1905, s. 289, 291.

${ }^{13}$ Niektórzy autorzy - powołując się zapewne na starożytne i wczesnochrześcijańskie teksty liturgiczne - wymieniają także i inne daty wspomnienia męczennicy z Meridy: 13 marca, 22 sierpnia|4 września i 16 grudnia. Zob. Kalendarium Carthaginense, [w:] Acta Martyrum. Theodorici Ruinart opera ac studio collecta, selecta atque illustrata accedunt praeterea in hac editione Acta ss. Firmi et Rustici, ed. T. Ruinart, Ratisbonae 1859, s. 633; Kalendarium Gothicum, [w:] Liturgia Mozarabica secundum regulam beati Isidori. Missale mixtum. Praefatione, notis et appendicibus. Breviarium Gothicum, t. 2, PL t. 86, Parisiis 1862, kol. 38, 44; Calendarium Mozarabicum saepius auctum, [w:] Liturgia Mozarabica secundum regulam beati Isidori. Missale mixtum. Praefatione, notis et appendicibus. Breviarium Gothicum, t. 1, PL t. 85, Parisiis 1862, kol. 96, 104; R. T. Hampson, Medii Aevi Kalendarium or dates, charters, and customs of the Middle Ages, with kalendars from the tenth to the fifteenth century and an alphabetical digest of obsolete names of days: forming a glossary of the dates of the Middle Ages, with tables and other aids for ascertaining dates, vol. 2, London 1841, s. 123; J. [T. Jagodziński], Eulalja, święta..., dz. cyt., s. 108.

${ }^{14}$ Owe jedenaście ksiąg - zatytułowane Carmina lub Miscellanea - skompletowane podobno zostało z inicjatywy św. Grzegorza z Tours. Zob. J. Czuj, Patrologia, Poznań 1953, s. 197-198; G. Rauschen, Zarys Patrologii. Pisma Ojców Kościoła i nauka w nich zawarta, Poznań-WarszawaWilno-Lublin 1929, s. 376-378. 
za jednego z wybitniejszych poetów chrześcijańskich, a część badaczy określa go nawet mianem poprzednika trubadurów ${ }^{15}$.

Ze wspomnianego hymnu pochodzi następujący passus, zawierający odwołanie do dziejów św. Eulalii:

Justynę w Padwie, Eufemię aż dotąd Chalcedon ukazuje,

Eulalia z Meridy podnosi głowę.

Cecylię Sycylia wspomina, Seleucia Teklę ${ }^{16}$.

Hiszpańska męczennica została tu wymieniona pośród innych dziewic, które poniosły śmierć za wiarę w czasie prześladowań za panowania cesarza Dioklecjana oraz cieszyły się szczególną popularnością we wczesnym średniowieczu, jako

${ }^{15}$ Określenie to uzasadnia także prowadzony przez Fortunatusa styl życia. Zanim bowiem został on biskupem Poitiers odbywał liczne podróże, w czasie których przyjmowany był na wielu dworach królewskich i książęcych, co też zaowocowało powstaniem licznych biletów, gratulacji i wierszy okolicznościowych jego autorstwa. Zob. J. de Ghellinck, Littérature latine au Moyen Âge, t. 1: Depuis les origines jusqu’a la fin de la Renaissance carolingienne, Paris 1939, s. 45; W. P. Ker, Wczesne średniowiecze (zarys historii literatury), Kraków-Gdańsk -Wrocław-Warszawa 1977, s. 97-101; Wenancjusz Fortunatus (Venantius Honorius Clementianus Fortunatus), [w:] Słownik wczesnochrześcijańskiego piśmiennictwa [dalej: swP], red. J. M. Szymusiak, M. Starowieyski, Poznań 1971, s. 288-289. Specyfikę stylu poetyckiego sekretarza św. Radegondy H. Waddell ujął w następujący sposób: „Et dans le monde farouche, quoique non dépourvu d’humour, de Grégoire de Tours, dans ce monde brutal et dépravé, les aperçus qu'il (Fortunat) donne de chose charmantes, un perroquet vert sur une tapisserie, des violettes et des primevères sur l'autel à Pâques, le clair de lune sur le pavement d'une église, sont la preuve que le sens de la beauté subsistait" (H. Waddell, Wandering Scholars, Londres-Constable 1927, s. 30).

${ }^{16}$ Tłumaczenie i podkreślenie własne. Venantius Honorius Clementius Fortunatus, De virginitate (liber VIII, carmen III), [w:] Venanti Honori Clementiani Fortunati presbyteri Italici opera poetica, Berlin-Weimar 1881 [przedruk. 1961], s. 185 (Monumenta Germaniae Historica inde ab anno Christi 500 usque ad annum 1500. Auctores Antiquissimi, 4, 1): „Justinam Patavi, Eufemiam huc Calchedon offert,| Eulalia Emerita tollit ab urbe caput.| Caeciliam Sicula profert, Seleucia Theclam". Przy czym Admonitio in 'Martyrium S. Euphemiae virginis', [w:] Acta Martyrum. Theodorici Ruinart opera ac studio collecta, selecta atque illustrata accedunt praeterea in hac editione Acta ss. Firmi et Rustici, ed. T. Ruinart, Ratisbonae 1859, s. 513 podaje nieco inne brzmienie pierwszego z cytowanych wersów: „Justinam Patavum, Euphemiam huc Calcedon effert”. Różnice owe wynikają zapewne $\mathrm{z}$ faktu, iż obie te publikacje sporządzono na podstawie dwóch różnych redakcji hymnu Fortunatusa. Natomiast źródło wskazanych odmienności upatrywać można choćby w niezamierzonych błędach kopistów, którzy pomieszali litery bądź grupy liter, mające w danej epoce jednakową wartość fonetyczną lub też źle odczytali przepisywany tekst, bowiem kształt liter lub system skrótów nie był im dobrze znany. Zob. B. Bravo, Krytyka tekstu, [w:] Vademecum historyka starożytnej Grecji i Rzymu. Źródłoznawstwo starożytności klasycznej, t. 1-2, pod. red. E. Wipszyckiej, Warszawa 2001, s. 515. 
wzór życia cnotliwego i w pełni poświęconego Bogu. Chodzi tu o święte: Justynę, Eufemię, Cecylię i Teklę. Na uwagę zasługują zwłaszcza dwie ostatnie postaci. Według zapisów apokryficznych św. Tekla miała być uczennicą i towarzyszką św. Pawła, a także pierwszą męczennicą. Szczególne zaś znaczenie św. Cecylii, nie tylko jako patronki muzyki kościelnej, najwyraźniej zamanifestowało się wpisaniem jej imienia do Kanonu rzymskiego ${ }^{17}$. Fakt pojawienia się Eulalii w takim „towarzystwie” przemawiałby za rozkwitem jej kultu na ziemi galijskiej w VI stuleciu. Z kolei wyraźna identyfikacja pochodzenia świętej wskazuje, iż chodzi tu o męczennicę z Meridy, nie zaś o jej imienniczkę z Barcelony.

Tekst kolejnego dzieła poetyckiego, będącego pochwałą niewinności, w którym św. Eulalia wymieniona została jako jedna z godnych naśladowania dziewiczych męczennic, powstał blisko sto lat później. Chodzi tu o De virginitate ( $O$ dziewictwie) pióra pierwszego pisarza angielskiego, mnicha i erudyty - Aldhelma z Malmesbury (zm. 709) ${ }^{18}$. Utwór ten - znany w dwóch wersjach: poetyckiej i prozatorskiej - cieszył się dużą popularnością już w świecie karolińskim i po dzień dzisiejszy uchodzi za główne dzieło tegoż autora. Współcześni badacze zwracają jednak uwagę, iż - mimo olbrzymiej ilości przytoczonych w nim przykładów biblijnych i historycznych - ów erudycyjny popis nie wniósł do skarbca patrystyki żadnych nowych myśli, a świadczy tylko o rozległym oczytaniu Aldhelma ${ }^{19}$.

${ }^{17} \mathrm{~W}$ literaturze hagiograficznej św. Cecylia w pierwszej kolejności łączona jest z rzymskimi katakumbami Kaliksta, gdzie odnaleziono jej relikwie, lub też z zatybrzańską bazyliką, do której je translokowano. Natomiast nieco zaskakujące powiązanie patronki muzyki z Sycylią tłumaczone jest przez związki rodzinne - według późnej tradycji święta miała z tej wyspy pochodzić. Zob. P. Guéranger, Sainte Cécile et la societé romaine, Paris 1877; J. P. Kirsch, Die heilige Caecilia in der römischen Kirche, Padeborn 1910. Na temat św. Tekli - zob. A. J. Festugiére, Sainte Thécle, Saints Côme et Damien, Saints Cyr et Jean, Saint George, Paris 1971. Zaś krótkie notki na temat dwóch pozostałych wzmiankowanych tu świętych zawierają np: Asteriusz z Amazji, [Obraz męczeństwa św. Eufemii], [w:] Męczennicy, red. E. Wipszycka, M. Starowieyski, Kraków 1991, s. 486-488; H. Fros, F. Sowa, Twoje imię..., dz. cyt., s. 328-329; W. Zaleski, Święci na każdy dzień, Warszawa 2001, s. 612-613.

${ }^{18}$ Zob. D. Attwater, The penguin dictionary..., dz. cyt., s. 120; D. H. Farmer, The Oxford Dictionnary..., dz. cyt., s. 169; V. Saxer, Eulalia di Mérida..., dz. cyt., kol. 128o. Publikacje powyższe wspominają tylko lakonicznie o przytoczeniu przez Aldhelma przykładu św. Eulalii, nie podając na ten temat żadnych bliższych informacji. A co więcej - nie uwzględniają one faktu istnienia w rzeczonym dziele dwóch wzmianek o męczennicy hiszpańskiej i mówią wyłącznie o jednym fragmencie.

${ }^{19}$ Jak zauważa W. P. Ker sam Aldhelm zaproponował dwa alternatywne określenia swojego stylu - „verbosa garrulitas” [słowne gadulstwo] albo „garrula verbositas” - [rozgadane wielosłowie] i pozostaje tylko problem, które z nich jest trafniejsze. Zob. W. P. Ker, Wczesne średniowiecze..., dz. cyt., s. 112. Por. A. Bober, Studia i teksty patrystyczne, Kraków 1967, s. 69-72; J. de Ghellinck, 
Rozdział 46. prozatorskiej wersji hymnu przywołuje postaci dwóch dziewicmęczennic, z których jedną jest św. Eulalia:

A i także pominięcie osób sławetnych panien, Tekli oraz Eulalii, odpowiadających wzorowi dziewiczej natury, uznałem za niewłaściwe; [...] Eulalię zaiste, obdarzoną podwójnym triumfem, mającą zarówno i zwycięsko zakończyć bieg i ustrzec wiary, wpisuje się do niebieskiego pocztu. Bowiem po chwale dziewictwa przynoszącego rozgłos, tak dalece przestraszyła się plugastwa cielesnego ścieku i pogardziła pożyciem małżeńskim, [że] szczęśliwie doszła do chwalebnej palmy męczeństwa ${ }^{20}$.

Urywek ten stanowi pochwałę rzeczonej świętej - stawianej tu na równi ze wspomnianą już św. Teklą - z racji nie tylko jej męczeńskiej śmierci, ale również życia hołdującego ideałowi dziewictwa. Ze względu też na te dwie zasługi autor mówi o podwójnym triumfie męczennicy. Określenie zaś hiszpańskiej świętej, jako mającej zarówno zwycięsko ukończyć bieg, jak i ustrzec wiary stanowi jawne nawiązanie do Pawłowej nauki o nadziei życia wiecznego jako nagrody za wierność Chrystusowi ${ }^{21}$.

Z kolei w wierszowanej wersji De virginitate znajduje się następujący fragment, mówiący o postaci św. Eulalii:

Eulalię rozsławianą niegdyś prozatorskimi pochwałami

Niechaj [tą] świętą starają się teraz czcić wierszowane pieśni.

Która [to] niczego śmiertelnego nie umiłowała próżną miłością,

Ani nie kłopotała się, by cokolwiek przedkładać ponad Najwyższego.

5 Lecz wzgardziła jednako wszelkim wspaniałym przepychem,

Aby całkowicie odrzuciwszy tak jak brukającą nieczystość

Uciechy kosztowności, postępowała wolna za Chrystusem.

Littérature latine au Moyen Âge..., dz. cyt., s. 39-40; Aldhelm (Eadhelm ep. Scireburensis), [w:] swP, dz. cyt., s. 20-21.

${ }^{20}$ Tłumaczenie własne. Aldhelmus, Tractatus sive ejus operum pars secunda. De laudibus virginitatis sive de virginitate Sanctorum, [w:] Octavi Saeculi ecclesiastici Scriptores. Opera omnia, t. 1, PL, t. 89, Parisiis 1863, kol. 146: „Necnon etiam gloriosas illustrium puellarum personas, Teclae et Eulaliae ad formam virginalis materiae congruentes, praeterire incommodum duxi; [...] Eulalia vero duplici praedita triumpho, et gemino ornata tropaeo cursum consummatura et fidem servatura coelesti inscribitur albo. Nam post rumigerulae virginitatis gloriam, qua carnalis cloacae spurcitias exhorruit, et nuptialis copulae contubernia sprevit, ad gloriosam martyrii palmam feliciter pervenit".

${ }^{21}$ Zob. $2 \operatorname{Tm}$ 4, 7. 
Ona [to pogardziła] przepychem małżeńskiej komnaty i wabiącymi radościami poduszek,

A także zlekceważyła dziedzictwo marnych [próżnych] godności:

10 Ażeby w niebiosach czystej cnoty miłośnik

Sędzia wszechmogący udzielił nagród za życie.

[Ten,] który zwykle zaszczyca czystych nieprzerwanymi triumfami

Oraz otwiera swoim rycerzom bramę przez jasne przestworza,

Gdy jako święci pokonują korzyści mamiącego świata

15 I niosą chorągwie uwieńczonym zastępem ${ }^{22}$.

Sądząc z uwagi zawartej w wersie 1, prozatorska wersja hymnu była wcześniejsza, a analizowany tu fragment jest jej późniejszym - wierszowanym - rozwinięciem. Całość stanowi pochwałę Eulalii, która nie dość, że pogardzała przyjemnościami doczesnymi - niezwykle sugestywnie przedstawionymi w wersie 8 za pomocą obrazu przepychu małżeńskiej komnaty i wabiących radości poduszek - to jeszcze złożyła swe życie w ofierze za wiarę. Byłoby to więc nawiązanie do podwójnego triumfu z wcześniej cytowanego passusu. Finalne wersety przytoczonego fragmentu wyrażają natomiast przekonanie autora - dotyczące już zapewne nie tylko św. Eulalii, ale i ogółu męczenników - iż umierający za Chrystusa są Jego szczególnymi naśladowcami i zostaną wynagrodzeni za swe poświęcenie szczęśliwością wieczną. W sposób wyjątkowy nagroda ta przynależeć będzie tym, którzy dla wiary zachowali również cnotę czystości, rozumianą tu in sensu largo, tj. jako niechęci do wszelkich korzyści mamiącego świata.

Warto zaznaczyć, iż nie ma stuprocentowej pewności co do tego, której z dwóch św. Eulalii dotyczą obydwa przywołane wyżej teksty Aldhelma. Nie zawierają one bowiem żadnych oczywistych wytycznych, umożliwiających bezsprzeczną

${ }^{22}$ Tłumaczenie i numeracja wersów własne. Wierszowana wersja utworu zaopatrzona jest także w dodatkowy podtytuł: De octo principalibus vitiis, gdyż jej ostatnie 460 wierszy - na ogólną liczbę 2900 - poświęcił autor opisowi alegorycznej walki dziewictwa z ośmioma[!] grzechami głównymi. Aldhelmus, Poemata sive ejus operum pars tertia. De laudibus virginum, [w:] Octavi Saeculi ecclesiastici Scriptores. Opera omnia, t. 1, PL, t. 89, Parisiis 1863, kol. 273: „Eulaliam prosae vulgatam laudibus olim| Metrica nunc studeant venerari carmina sanctam,| Quae mortale nihil vano dilexit amore,| Nec quidquam in mundo satagit praeferre Tonanti, || 5 Sed cunctas pariter pompas contempsit opimas,| Funditus ut spretis coeni squalentis ad instar| Deliciis gazae, sequeretur libera Christum.| Haec thalami luxus et gaudia blanda tororum,| Atque caducorum sortem despexit honorum:|| 10 Quatenus in coelis castae virtutis amator| Arbiter omnipotens impendat praemia vitae,|Qui solet assiduis castos ornare triumphis,| Militibusque suis portam reserare per aethram,| Dum vincunt sancti fallentis praemia mundi,|| 15 Atque coronatis gestant vexilla maniplis". 
identyfikację. Także data powstania utworu (druga połowa viI w.) nie stanowi tu dobrej wskazówki, gdyż rozwijał się już wtedy zarówno kult męczennicy z Meridy, jak i tej z Barcelony. Przyjmuje się jednak, iż większe jest prawdopodobieństwo dotarcia $\mathrm{w}$ tym okresie na Wyspy Brytyjskie sławy św. Eulalii z Emerita Augusta - której dzieje już co najmniej od trzech stuleci inspirowały autorów chrześcijańskich - niż jej imienniczki dopiero co „wylansowanej” przez biskupa Quiricusa.

Także na ziemi brytyjskiej, choć już w początkach viII wieku powstał inny hymn sławiący stan dziewiczy, w którym znaleźć można kolejne odwołanie do postaci św. Eulalii - Alma Deus Trinitas (Płodna Boska Trójca). Jego autorem jest najwybitniejszy Ojciec Kościoła Anglosaskiego - Beda Venerabilis (zm. 735), którego olbrzymi i niezwykle zróżnicowany dorobek pisarski wieńczy monumentalna monografia początków narodu angielskiego - Historia Ecclesiastica Gens Anglorum $^{23}$. Obejmuje ona w pięciu księgach dzieje Brytanii od czasów podboju Cezara do chwili powstania dzieła (tj. do 731). Zaś w jej czwartej części autor zamieścił dodatkowo wzmiankowany wyżej poemat - dedykowany królowej Etheldredzie $^{24}$ - z którego pochodzi następujący wyjątek:

Jej [Dziewicy Maryi] cześć zrodziła z czystego nasienia liczne,

Dziewicze kwiaty jej cześć zrodziła.

Palona okrutnymi płomieniami nie ustępuje dziewica Agata,

\section{Eulalia wytrzymuje palona okrutnymi płomieniami.}

Zwycięża dzikie zwierzęta przez wzniosłość duszy niewinna Tekla,

Eufemia święta [i] niewinna zwycięża dzikie zwierzęta.

Śmieje się z mieczy silniejsza od żelaza radosna Agnieszka,

Cecylia radosna wyśmiewa nieprzyjacielskie miecze.

${ }^{23}$ R. Dybowski podkreśla znaczenie Historii Kościelnej Narodu Angielskiego jako „najobszerniejszej, jaką posiadamy, dawnej historii Wysp Brytyjskich”, a przy tym „arcydzieła nie tylko szczerego i metodycznego poszukiwania prawdy, ale także znakomitego w swej szlachetnej prostocie stylu literackiego" (R. Dybowski, Wielkie dni katolicyzmu angielskiego, [w:] Między literaturą a życiem, Warszawa 1936, s. 9). Por. A. Bober, Studia i teksty..., dz. cyt., s. 98, 104-105; M. Kordel, W 120o-tna rocznicę śmierci św. Bedy Wielebnego (26.v.735 - 26.v.1935), „Misterium Christi” 35 (1934) nr 6, s. 103-105; Sz. Pieszczoch, Wprowadzenie w studium Ojców Kościoła, Poznań-Warszawa-Lublin 1964, s. 173; E. Sarnowska-Temeriusz, Zarys dziejów poetyki (od starożytności do końca XVII w.), Warszawa 1985, s. 235; Beda Wielebny albo Czcigodny (Beda Venerabilis), [w:] swp, dz. cyt., s. 74-113.

${ }^{24}$ Chodzi tu o żyjącą na przełomie viı i viII wieku królową Northumbrii, a później opatkę z Ely, która dzięki swojemu wielkiemu talentowi organizacyjnemu oraz świętości życia przyczyniła się do szerzenia nauki i religii na Wyspach Brytyjskich. Zob. V. Blanton, Signs of Devotion. The cult of St Aethelthryth in medieval England (695-1615), University Park (PA) 2007. 
Wielki triumf panuje w świecie przez skromne serca,

Wielkie umiłowanie skromności panuje w świecie ${ }^{25}$.

Podobnie, jak w analizowanym wcześniej fragmencie hymnu Wenancjusza Fortunata, również i w tym przypadku św. Eulalia wymieniona została wśród najbardziej znanych dziewic-męczennic z pierwszych wieków chrześcijaństwa. Ponownie pojawiły się tu imiona św. Tekli, Eufemii i Cecylii, zaś Beda dołożył jeszcze w stosunku do swego frankijskiego poprzednika wspomnienie o świętych Agacie i Agnieszce ${ }^{26}$. Dodatkowo również triumf każdej z owych męczennic podkreśla króciutki opis rodzaju śmierci, jaką poniosły, w zależności od czego także bohaterki zostały dobrane do siebie parami. Stąd też św. Eulalia występuje obok św. Agaty, bowiem obie te męczennice zginąć miały w płomieniach. Ten zresztą element przemawia również za hipotezą, iż autor miał na myśli świętą z Meridy, której - w odróżnieniu od barcelońskiej imienniczki - przypisywano śmierć na stosie. Mimo tych drastycznych szczegółów całość emanuje mistyczną wręcz radością, dzięki wielokrotnym podkreśleniom, iż słabe niewiasty odniosły zwycięstwo nad brutalnością katów i wytrwały w wierze, nie zważając na straszliwe tortury. Zwraca wreszcie uwagę fakt, iż - inaczej niż w starszych hymnach czystość Eulalii i jej „towarzyszek” wydaje się tu mieć swoje umocowanie nie tyle w chęci naśladowania Chrystusa, co w dziewictwie Jego Matki.

Najbardziej jednak spektakularnym przykładem odbicia kultu hiszpańskiej świętej w twórczości poetyckiej wieków średnich jest La Cantilène de Sainte Eulalie (Kantylena o świętej Eulalii). Utwór ten, mimo swych niewielkich rozmiarów, stanowi jeden $z$ najważniejszych tekstów literatury europejskiej ${ }^{27}$. Jest on bowiem

${ }^{25}$ Tłumaczenie i podkreślenie własne. Beda Venerabilis, Historia ecclesiastica, [w:] Venerabilis Bedae Anglo-Saxonis presbyteri opera omnia, t. 6, PL, t. 95, Parisiis 1863, kol. 204: „Hujus [Mariae Virginis] honor genuit casto de germine plures, | Virgineos flores hujus honor genuit.| Ignibus usta feris virgo non cessat Agatha,| Eulalia et perfert ignibus usta feris.| Casta teras superat mentis pro culmine Tecla,| Euphemia sacra casta feras superat.| Laeta ridet gladios ferro robustior Agnes,| Caecilia infestos laeta ridet gladios.| Multus in orbe viget per sobria corda triumphus,| Sobrietatis amor multus in orbe viget".

${ }^{26}$ Św. Tekla, św. Eufemia, św. Cecylia - zob. przyp. nr 17 w niniejszym artykule; o św. Agacie i św. Agnieszce - zob. A. J. Smith, Life of st. Agnes, Virgin and Martyr, Charleston 2008; H. Fros, Martyrologium..., dz. cyt., s. 24, 33; H. Fros, F. Sowa, Twoje imię..., dz. cyt., s. 75-77 (tam dalsza literatura).

${ }^{27}$ Kantylena definiowana jest jako „krótka pieśń epicka w poezji średniowiecznej, zwł. starofrancuskiej, wykonywana zwykle z towarzyszeniem muzyki” (Słownik wyrazów obcych, Warszawa 1991, s. 400). Zob. J. Adamski, Historia literatury francuskiej. Zarys, Wrocław-WarszawaKraków-Gdańsk-Łódź 1989, s. 18; R. Berger, A. Brasseur, Les Séquence de Sainte Eulalie, Genève 
pierwszym dziełem napisanym w potocznym języku francuskim, a ściślej w jego dialekcie pikardyjsko-wallońskim ${ }^{28}$. Jedyny znany manuskrypt poematu zachował się właściwie dzięki przypadkowi. Został on bowiem zapisany, obok pięciu innych pieśni, na ostatnich wolnych stronach w zbiorze mów św. Grzegorza z Nazjanzu ${ }^{29}$. Dzieło to od czasów Rewolucji Francuskiej spoczywało w bibliotece opactwa Saint-Amand (Elone), blisko Valenciennes. Tam też miało miejsce jego odkrycie, dokonane w 1837 roku przez poetę i filologa Hermanna von Fallersbena, który jako pierwszy zabytek ten opublikował ${ }^{30}$. Kantylena dotrwała do chwili obecnej w dwóch wersjach językowych: łacińskiej i francuskiej, nie zachowała się natomiast melodia, na którą miała być śpiewana ${ }^{31}$. Całość składa się z dwudziestu dziewięciu wersów o rytmicznej konstrukcji, ujętych w czternaście zwrotek.

2004; G. Hilty, La Séquence de Sainte Eulalie et les origines de la langue littéraire française, „Vox Romanica” 27 (1968), s. 4-18; L. C. Porter, The „Cantilène de sainte Eulalie”. Phonology and Graphemics, „Studies in Philology” 47 (1960), s. 587-596; Histoire de la littérature française. Du Moyen Âge au XVIIIe siècle, éd. P. Brunel, Bordas 1986, s. 10.

${ }^{28}$ Zob. P. Marchot, Sur le dialecte de l'Eulalie, „Zeitschrift für romanische Philologie” 20 (1896), s. 510-514; P. Marchot, Les principaux traits morphologiques $d u$ wallon pré-littéraire ou préhistorique (500-80o), „Zeitschrift für französische Sprache und Literatur” 41 (1913), s. 233-256.

${ }^{29}$ Wśród owych pięciu pieśni, trzech religijnych i dwóch świeckich, znalazł się także jeden z pierwszych zabytków języka germańskiego - Rithmus Teutonicus, sławiący zwycięstwo Ludwika III nad Normanami w Saucourt-en-Vimeu w 881 roku. Oba te utwory miały najprawdopodobniej takie samo przeznaczenie - czytano je w trakcie posiłków dla zbudowania, i po trosze rozrywki, słuchających. Zob. A. Faugère, Le „Rithmus teutonicus” et La "Cantilène de sainte Eulalie”, [w:] La Cantilène de sainte Eulalie. Actes du colloquie de Valenciennes, Valenciennes 1989, s. 97-100.

${ }^{30}$ Obecnie księga ta znajduje się w Bibliotece Miejskiej w Valenciennes z sygnaturą ms 150. Liczy ona 143 karty, przy czym Kantylena znajduje się na stronach: f. 141 r. i f. 141 v. Całość oprawiona jest w źle zachowaną jelenią skórę ze śladami włosia (stąd inna nazwa tego dzieła - liber pilosus, tj. „księga owłosiona”). Rozmiary oprawy: 245|152 mm, stron pergaminowych: 233|150 mm. Zob. R. Bossuat, J. Monfrin, Manuel bibliographique de la littérature française du Moyen Âge, Melun 1951, s. 6.

${ }^{31}$ F. Wolf jako pierwszy wysunął przypuszczenia, iż wersja łacińska i francuska utworu śpiewana była na tę samą melodię, zaś niespełna sto lat później opinię tę potwierdził P. Zumothor. Zob. F. Wolf, Über die Lais, Sequenzen und Leiche. Ein Beitrag zur Geschichte der rythmischen Formen und Singweisen der Volkslieder und der volksmässigen Kirchen - und Kunstlieder im Mittelalter, Leipzig 1841, s. 117; P. Zumothor, Langue et techniques poétiques á l'époque romane, Paris 1963, s. 53. Z kolei studia nad rytmem i akcentami w Kantylenie o św. Eulalii przeprowadzili S. Eriga i P. Porteau. Zob. S. Eriga, La versification de la „Sainte Eulalie”, „Neophilologus” 9 (1926), s. 1-8; P. Porteau, La "Cantilène de sainte Eulalie” serait - elle un poéme strophique?, „Revue de linguistique romane” 9 (1933), s. 152-165. Natomiast rozważania nad stopniem wzajemnej zależności między obydwoma wersjami językowymi pieśni przedstawiono w: P. Verrier, Le vers français. Formes primtives, développement, diffusion, t. 2, Paris 1932, s. 98-118. 
Z dziełem tym wiąże się szereg niejasności. W pierwszej kolejności dotyczą one kwestii datowania, miejsca powstania i autorstwa tekstu. Przyjmuje się obecnie, iż kodeks, w którym zapisano Kantylenę pochodzi z pracowni lotaryńskiej, istniejącej przy - wspomnianym już - klasztorze Saint-Amand, które to opactwo uległo zniszczeniu w wyniku najazdów normańskich w 881 i 883 roku Stąd też daty te uchodzą za terminus post quem non i uznaje się powszechnie, iż utwór został napisany około 882 roku $^{32}$. Co zaś się tyczy autorstwa pieśni - mimo wieloletnich na ten temat dyskusji - pozostaje ono nadal anonimowym. Najnowsze badania zdają się jednak wskazywać na Hucbalda z Saint-Amand (zm. 930), o którym opinia jako o kompozytorze dorównuje jego reputacji jako poety i teoretyka literatury ${ }^{33}$.

Sam zaś tekst Kantyleny brzmi w sposób następujący:

Eulalia była dobrą, młodą dziewczyną.

Miała piękne ciało, lecz duszę jeszcze piękniejszą.

Nieprzyjaciele Boga chcieli ją pokonać;

Chcieli aby służyła Diabłu.

5 [Lecz ona] nie słucha złych doradców

którzy od niej żądają, aby wyparła się Boga, który jest w niebie tam wysoko,

Ani dla złota, ani dla srebra, ani dla biżuterii

Ani przez groźbę ani przez prośby władcy.

Nic nie mogło nigdy [jej] ugiąć ani doprowadzić do tego, aby

10 Młoda dziewczyna nie kochała zawsze służby Bożej.

I z tej przyczyny została ona przedstawiona Maksyminowi,

Który był w tym czasie królem pogan.

On jej rozkazał, lecz mało ją [ten rozkaz] obchodzi,

Aby wyrzekła się imienia chrześcijanki.

15 Ona zbiera swe siły.

Woli znosić tortury raczej niż, ażeby

Miała stracić swe dziewictwo.

To dlatego umarła w takiej chwale.

${ }^{32}$ Zob. T. Alkire, C. Rosen, Romance Languages. A Historical Introduction, Cambridge 2010, s. 205 .

${ }^{33}$ Zob. Y. Chartier, L'auteur de la Cantilène de sainte Eulalie, [w:] Chant and its Peripheries. Essays in Honour of Terence Bailey, ed. B. Gillingham, P. Merkely, Ottawa 1998, s. 159-178. Natomiast już na początku ubiegłego stulecia zwrócono uwagę, iż autorem Kantyleny był twórca znajdujący się pod wpływem filozofii Jana Szkota Eriugeny. Zob. J. Györy, Le système philosophique de Jean Scot Érigéne et la „Cantiléne de sainte Eulalie”, „Egyetemes Philologiai Kózlöny” 6o (1936), s. 29-37. 
Ciskają ją w ogień, aby ją spalić żywcem.

20

Ona nie zgrzeszyła, więc nie spłonęła natychmiast.

Pogański władca nie chciał się na to zgodzić.

[Więc] rozkazał ściąć jej głowę mieczem.

Dziewczyna nie opierała się temu.

Chce ona [już] opuścić świat; modli się do Chrystusa

25 Pod postacią gołębia [dusza jej] wzlatuje do nieba.

Módlmy się wszyscy, by raczyła wstawiać się za nami.

Aby Chrystus okazał nam litość

Po śmierci i pozwolił nam przyjść do Siebie

Przez swe miłosierdzie ${ }^{34}$.

Autor pieśni niewiele podaje konkretnych informacji hagiograficznych i nie wspomina praktycznie o życiu Eulalii przed męką. Skupia się natomiast na jej licznych zaletach, gorliwości w służbie Bogu oraz umiłowaniu dziewictwa ${ }^{35}$. Po raz pierwszy jednak pojawia się tu zapis, według którego święta stanęła nie przed sądem namiestnika Hiszpanii, lecz samego Maksymina - władcy pogańskiego ${ }^{36}$ (wersety 11-13 oraz 21-22). I to właśnie z jego rozkazu miała ona ponieść śmierć męczeńską.

${ }^{34}$ Tłumaczenie własne. Recueil d’anciens textes bas-latins provençaux et français, éd. P. Meyer, Paris 1874, s. 194-195. Por. Ch. J. B. Bunsen, Christianity and mankind. Their beginnings and prospects, vol. 2, London 1854, s. 40: „Buona pulcella fut Eulalia.|| Bel avret corps, bellezour anima.| Voldrent la veintre li Deo inimi,| Voldrent la faire diaule servir.|| 5 Elle no'nt eskoltet les mals conselliers| Qu'elle De o raneiet, chi maent sus en ciel,| Ne por or ned argent ne paramenz| Por manatce regiel ne preiement.| Niule cose non la pouret omque pleier|| 10 La polle sempre non amast lo Deo menestier.| E por o fut presentede Maximiien,| Chi rex eret a cels dis soure pagiens.| Il li enortet, dont lei nonque chielt,| Qued elle fuiet lo nom chrestiien.|| 15 Ell'ent adunet lo suon element:| Melz sostendreiet les empedementz| Qu'elle perdesse sa virginitét;| Por os furet morte a grand honestét.| Enz enl fou lo getterent com arde tost.|| 20 Elle colpes non avret, por o nos coist.| A czo nos voldret concreidre li rex pagiens.| Ad une spede li roveret tolir lo chieef.| La domnizelle celle kose non contredist:| Volt lo seule lazsier, si ruovet Krist|| 25 In figure de colomb volat a ciel.| Tuit oram que por nos degnet preier| Qued auuisset de nos Christus mercit| Post la mort et a lui nos laist venir|| Par souue clementia”.

${ }^{35} \mathrm{Na}$ temat chrześcijańskiego rozumienia dziewictwa św. Eulalii oraz jego znaczenia w świetle Kantyleny F. J. Barnett wypowiedział się w sposób następujący: „Virginity is the spiritual virginity of a soul faithful to Christ, a virginity Eulalia will never consent to lose by apostasy or idolatry, whatever the penalties inflicted on her" (F. J. Barnett, "Virginity" in the old french Sequence of Saint Eulalia, „French Studies” 13 [1959], s. 255).

${ }^{36}$ Zapewne chodzić by tu miało o Maksymina Daję - cesarza w latach 305-311. Zob. M. Jaczynowska, Historia starożytnego Rzymu, Warszawa 1978, s. 349, 351-352; S.B. [S. Bralewski], Maksymin 
Inny element dziejów hiszpańskiej bohaterki, który znany jest jedynie z Kantyleny, to cud związany z jej męką. Przy czym poeta posłużył się owym niezwykłym wydarzeniem, aby wytłumaczyć, dlaczego święta ta zginęła od miecza. Chodzi tu o zapis z wersu 20, który mówi, iż ogień nie czynił żadnej szkody torturowanej męczennicy, wobec czego cesarz musiał skazać ją na inny rodzaj śmierci. Oprócz tego autor przytacza także wzmiankowaną już informację o ukazaniu się duszy zmarłej bohaterki pod postacią odlatującej do nieba gołębicy (werset 25). Całość kończy się, charakterystycznym dla tego typu utworów, wezwaniem do modlitwy oraz wyrażeniem wiary w orędownictwo świętej u tronu Chrystusowego (wersy 26-29).

Na marginesie dodać można, iż - obok przytoczonych powyżej wątków hagiograficznych - dokładna analiza rzeczonego utworu zrodziła również wiele niejasności o charakterze językoznawczym. Szczególnie dużo wątpliwości badaczy budzi werset 15 Kantyleny, a ściślej dwa spośród występujących w nim wyrazów. Polemiki specjalistów dotyczą bowiem znaczenia rzeczownika element oraz prawidłowego brzmienia formy adunet, którą część paleografów odczytuje jako aduret ${ }^{37}$.

Niezależnie od wszelkich niejasności, jakie związane są z Kantyleną o św. Eulalii, utwór ten stanowi dowód istnienia na terenie Galii w Ix stuleciu ośrodków kultu tejże męczennicy. Zaś fakt, iż najstarszy zabytek języka francuskiego opiewa tę właśnie postać, uznać można za niemalże symboliczne świadectwo obecności czci wobec hiszpańskiej świętej w religijności średniowiecznych mieszkańców dzisiejszej Francji.

\footnotetext{
Daja, [w:] Słownik cesarzy rzymskich, red. J. Prostko-Prostyński, Poznań 2001, s. 228-229.

${ }^{37}$ Jako pierwszy wątpliwości w tej materii zgłosił G. G. Nicholson. Przekładając utwór na język francuski, postawił on bowiem w opozycji wobec siebie dwie możliwe do odczytania wersje rzeczonego czasownika: repondre $=$ „odpowiedzieć, reagować” oraz repliquer $=$ „replikować”. Zob. G. G. Nicholson, Le passage controversé de la „Cantilène de sainte Eulalie”, [w:] Recherches philologiques romanes, Paris 1921, s. 242-245. Dwadzieścia lat później kwestię tę podjął ponownie H. D. Learned w pracy: The Eulalia Ms. at line 15 reads „aduret” not „adunent”, „Speculum” 16 (1941), s. 334-335. A wreszcie J. Orr - odrzucając poglądy Nicholsona - odczytał problematyczny wyraz w brzmieniu adunet i zinterpretował go jako francuskie affirmer $=$ „twierdzić, postulować z energią”. Badacz ten opowiedział się również za rozumieniem drugiego spornego słowa: element jako „zasadę, prawo”. Zob. J. Orr, Sur un vers de l'Eulalie, [w:] Essais d'étymologie et de philologie françaises, Paris 1963, s. 165-172. Podczas gdy już dekadę wcześniej zaproponowano inne znaczenie tegoż rzeczownika - „substancja, anima”. Zob. A. Granville-Hatcher, Eulalia, lines 15-17, „Romanic Review” 40 (1949), s. 241-249.
} 


\section{Podsumowanie}

Omówione w niniejszym artykule poematy zachodnioeuropejskie, powstałe na przestrzeni wieków od VI do IX, stanowią ważną grupę świadectw istnienia i rozwoju kultu św. Eulalii z Meridy. Wskazują one bowiem, iż we wczesnym średniowieczu postać hiszpańskiej męczennicy znana była i czczona także poza rodzimym Półwyspem Pirenejskim, na terenie dzisiejszej Francji oraz na Wyspach Brytyjskich. Co więcej, tamtejsi autorzy stawiali ją na równi z tak popularnymi bohaterkami starożytności chrześcijańskiej jak: Agnieszka, Tekla czy Agata. Ciekawą kwestią - choć bezsprzecznie przekraczająca ramy niniejszego artykułu - pozostaje pytanie, na ile obraz ten potwierdzają inne zachowane źródła (adnotacje w martyrologiach, teksty liturgiczne, dzieła sztuki sakralnej).

Warto też zaznaczyć, iż wspólnym mianownikiem analizowanych utworów jest pochwała czystości. Poza przynależnością do grupy tekstów związanych z chrześcijańskim kultem męczenników, wpisują się one w nurt literatury patrystycznej poświęconej rozważaniom nad wartością dziewictwa. Piśmiennictwo to wyrasta zaś z przekonania, iż zachowanie czystości - podobnie jak i męczeństwo - oznacza przede wszystkim doskonałą wierność Bogu, a co za tym idzie - męczennik i dziewica (albo jeszcze lepiej dziewica-męczennica) to postaci najlepiej realizujące wzorzec życia chrześcijańskiego. Stanowisko to korzeniami swymi sięga do nauk św. Pawła $\mathrm{z}$ Tarsu, zaś w okresie późniejszym podsycane było utworami pokroju Uczty dziesięciu dziewic Metodego z Olimpu czy nauczaniem św. Augustyna o grzechu pierworodnym i cielesności człowieka ${ }^{38}$. Natomiast omawiane przykłady pokazują, iż w dobie wczesnego średniowiecza pochwała czystości nadal żywo była obecna w literaturze religijnej, choć z biegiem czasu jej bazą stało się przede wszystkim odniesienie do wzoru Najświętszej Maryi Panny.

${ }^{38}$ Zob. F. Drączkowski, Patrologia, Pelplin-Lublin 1998, s. 164-169; M. Michalski, Antologia literatury patrystycznej, t. 1, Warszawa 1975, s. 426-441; A. Swoboda, Nauka o świętym dziewictwie w pismach św. Augustyna, „Poznańskie Studia Teologiczne” 20 (2006), s. 99-115. 


\section{Streszczenie}

Artykuł poświęcony został hiszpańskiej męczennicy z okresu prześladowań Dioklecjana - Eulalii z Meridy, a ściślej zachowanym do dnia dzisiejszego średniowiecznym utworom poetyckim, które postać tę przywołują. Ów zbiór pięciu tekstów źródłowych tworzony przez fragmenty poematów Wenancjusza Fortunatusa, Aldhelma i Bedy Czcigodnego oraz Kantylenę o św. Eulalii - poddany została analizie pod kątem wykazania rozwoju kultu świętej zarówno w wymiarze terytorialnym, jak i czasowym. Zwrócono przy tym uwagę na wspólne wątki hagiograficzne i ogólnoreligijne obecne w rozważanych źródłach. Dla ułatwienia każdy z tekstów opatrzono także polskim tłumaczeniem. Całość analizy poprzedzona została zarysem dostępnych współcześnie informacji na temat dziejów św. Eulalii.

\section{Słowa kluczowe}

św. Eulalia z Meridy, Wenancjusz Fortunat, Aldhelm, Beda Czcigodny, Kantylena o św. Eulalii, kult męczenników

\section{Abstract}

\section{St. Eulalia of Merida and the development of her cult in light of medieval poems}

The aim of the article is to present a Spanish martyr during Diocletianic persecution Eulalia of Merida, and, more specifically, medieval poems devoted to her that are preserved until now. A set of five primary sources - consisting of certain fragments of poems by Venantius Fortunatus, Aldhelm and Bede the Venerable as well as The Sequence of Saint Eulalia - has been analyzed in terms of demonstrating the development of sacred cult both in geographical as well as time dimensions. Special attention has been paid to the common hagiographic and general religious threads present in the discussed sources. In order to facilitate each text, the author also provides their Polish translations. The entire analysis is preceded by an outline of currently available information concerning the life of St. Eulalia. 


\section{Keywords}

Eulalia of Merida, Venantius Fortunatus, Aldhelmus, Beda Venerabilis, The Sequence of Saint Eulalia, the cult of martyrs

\section{Bibliografia}

\section{Źródła}

Acta Sanctorum. Novembris, t. 2, ed. H. Delehaye, P. Peeters, M. Coens, Bruxellis 1931.

Aldhelmus, Tractatus sive ejus operum pars secunda. De laudibus virginitatis sive de virginitate Sanctorum, [w:] Octavi Saeculi ecclesiastici Scriptores. Opera omnia, t. 1, Patrologiae cursus completus sive bibliotheca universalis, integra, uniformis, commoda, oeconomica omnium ss. Patrum, Doctorum Scriptorumque ecclesiasticorum, qui ab aevo apostolico ad usque Innocentii III (anno 1216) pro Latinis et concilii Florentini (ann. 1439) pro Graecis floruerunt. Series Latina), accurante J. P. Migne, t. 89, Parisiis 1863, kol. 146.

Aldhelmus, Poemata sive ejus operum pars tertia. De laudibus virginum, [w:] Octavi Saeculi ecclesiastici Scriptores. Opera omnia, t. 1, PL, t. 89, Parisiis 1863, kol. 273.

Beda Venerabilis, Historia ecclesiastica, [w:] Venerabilis Bedae Anglo-Saxonis presbyteri opera omnia, t. 6, PL, t. 95, Parisis 1863.

Venantius Honorius Clementius Fortunatus, De virginitate (liber VIII, carmen III), [w:] Venanti Honori Clementiani Fortunati presbyteri Italici opera poetica, Berlin-Weimar 1881 [przedruk 1961] (Monumenta Germaniae Historica inde ab anno Christi 500 usque ad annum 1500. Auctores Antiquissimi, 4, 1).

\section{Opracowania}

[Bralewski S.] S. B., Maksymin Daja, [w:] Słownik cesarzy rzymskich, red. J. Prostko-Prostyński, Poznań 2001, s. 228-229.

Adamski J., Historia literatury francuskiej. Zarys, Wrocław-Warszawa-Kraków-GdańskŁódź 1989.

Admonitio in „Martyrium S. Euphemiae virginis”, [w:] Acta Martyrum. Theodorici Ruinart opera ac studio collecta, selecta atque illustrata accedunt praeterea in hac editione Acta ss. Firmi et Rustici, ed. T. Ruinart, Ratisbonae 1859, s. 513-516.

Alkire T., Rosen C., Romance Languages. A Historical Introduction, Cambridge 2010.

Allard P., Dix leçons sur le martyre, Paris 1905.

Attwater D., The penguin dictionary of Saints, Harmondsworth 1982.

Barnett F. J., Virginity' in the old french Sequence of Saint Eulalia, „French Studies” 13 (1959), s. 252-256. 
Baudot J., Chaussin P., Vies des Saints et des Bienheureux selon l'ordre du calendrier avec l'histoire des fêtes, t. 2, Février, Paris 1936.

Bauer Z., Leszkiewicz A., Wielka księga świętych, t. 1, Kraków 2003.

Beda Wielebny albo Czcigodny (Beda Venerabilis), [w:] Słownik wczesnochrześcijańskiego piśmiennictwa, pod red. J. M. Szymusiaka, M. Starowieyskiego, Poznań 1971, s. 74-113. Berger R., Brasseur A., Les Séquence de Sainte Eulalie, Genève 2004.

Blanton V., Signs of Devotion. The cult of St Aethelthryth in medieval England (695-1615), University Park (PA) 2007.

Bober A., Studia i teksty patrystyczne, Kraków 1967.

Bossuat R., Monfrin J., Manuel bibliographique de la littérature française du Moyen Âge, Melun 1951.

Bravo B., Krytyka tekstu, [w:] Vademecum historyka starożytnej Grecji i Rzymu. Źródłoznawstwo starożytności klasycznej, t. 1-2, pod red. E. Wipszyckiej, Warszawa 2001, s. 512-541.

Brown P., The Cult of the Saints. Its Rise and Function in Latin Christianity, Chicago 1980. Bunsen Ch. J. B., Christianity and mankind. Their beginnings and prospects, vol. 2, London 1854.

Cammilleri R., Wielka księga Świętych Patronów, tłum. M. Radomska, Kielce 2002.

Charkiewicz J., Święte niewiasty. Mały leksykon hagiograficzny, Hajnówka 2001.

Chartier Y., L'auteur de la Cantilène de sainte Eulalie, [w:] Chant and its Peripheries. Essays in Honour of Terence Bailey, ed. B. Gillingham, P. Merkely, Ottawa 1998, s. 159-178.

Cirlot J. E., Słownik symboli, Kraków 2000.

Czuj J., Patrologia, Poznań 1953.

Drączkowski F., Patrologia, Pelplin-Lublin 1998.

Dybowski R., Między literaturą a życiem, Warszawa 1936.

Eriga S., La versification de la „Sainte Eulalie”, „Neophilologus” 9 (1926), s. 1-8.

Fàbrega-Grau A., Eulalie de Barcelone (Sainte), [w:] Dictionnaire d'Histoire et de Geographie ecclesiastiques, t. 15, éd. A. Baudrillart, Paris 1963, kol. 1381-1382.

Fàbrega-Grau A., Santa Eulalia de Barcelona: revision de un problema historico, Rome 1958.

Farmer D. H., The Oxford Dictionnary of Saints, New York 1992.

Faugère A., Le „Rithmus teutonicus” et La „Cantilène de sainte Eulalie”, [w:] La Cantilène de sainte Eulalie. Actes du colloquie de Valenciennes, Valenciennes 1989, s. 97-10o.

Fernández Catón J. M., Manifestaciones ascéticas en la iglesia hispano-romana del siglo IV, León 1962.

Ferretto G., Note storico-bibliografiche di archeologia cristiana, Città del Vaticano 1942.

Festugiére A. J., Sainte Thécle, Saints Côme et Damien, Saints Cyr et Jean, Saint George, Paris 1971.

Forstner D., Świat symboliki chrześcijańskiej, Warszawa 1990. 
Fros H., Martyrologium, czyli wspomnienia świętych przypadające na poszczególne dni roku, Warszawa 1984.

Fros H., Sowa F., Księga imion i świętych, t. 2, Kraków 1997.

Fros H., Sowa F., Twoje imię. Przewodnik onomastyczno-hagiograficzny, Kraków 1975.

Fros H., Wspomnienie świętych na każdy dzień roku. Martyrologium, Kraków 1992.

Garci-Villada Z., El problema de las dos santas Eulalias, „Razón y Fe” 68 (1920), s. 166-186.

Garciá-Villada Z., Historia ecclesiástica de España, t. 1, part 1, Madrid 1929.

Ghellinck J. de, Littérature latine au Moyen Âge, t. 1: Depuis les origines jusqu’á la fin de la Renaissance carolingienne, Paris 1939.

Giry F., Vies des Saints d'après les Bollandistes, Surius, Ribadereira, t. 12, Paris 1867.

Granville-Hatcher A., Eulalia, lines 15-17, „Romanic Review” 40 (1949), s. 241-249.

Guéranger P., Sainte Cécile et la societé romaine, Paris 1877.

Györy J., Le système philosophique de Jean Scot Érigéne et la „Cantiléne de sainte Eulalie”, „Egyetemes Philologiai Kózlöny” 6o (1936), s. 29-37.

Hampson T., Medii Aevi Kalendarium or dates, charters, and customs of the Middle Ages, with kalendars from the tenth to the fifteenth century and an alphabetical digest of obsolete names of days: forming a glossary of the dates of the Middle Ages, with tables and other aids for ascertaining dates, vol. 2, London 1841.

Hilty G., La Séquence de Sainte Eulalie et les origines de la langue littéraire française, „Vox Romanica” 27 (1968), s. 4-18.

Histoire de la littérature française. Du Moyen Âge au xvııIe siècle, éd. P. Brunel, Bordas 1986. Jaczynowska M., Historia starożytnego Rzymu, Warszawa 1978.

[Jagodziński T.] J., Eulalja, święta, panna i męczen., [w:] Encyklopedija kościelna, t. 5, red. M. Nowodworski, Warszawa 1874.

Ker W. P., Wczesne średniowiecze (zarys historii literatury), Kraków-Gdańsk-WrocławWarszawa 1977.

Kerler D. H., Die Patronate der Heiligen. Ein Alphabetisches Nachschlagebuch für Kirchen-, Kultur-, Kunsthistoriker, sowie für den praktischen Gebrauch des Geistlichen von..., Ulm 1905.

Kopaliński W., Słownik mitów i tradycji kultury, Warszawa 1985.

Kopaliński W., Słownik symboli, Warszawa 1990.

Kordel M., W 120o-tna rocznicę śmierci św. Bedy Wielebnego (26.v.735-26.V.1935), „Misterium Christi” 35 (1934) nr 6, s. 103-105.

Learned H. D., The Eulalia Ms. at line 15 reads „aduret” not „adunent”, „Speculum” 16 (1941), s. $334-335$.

Leclercq H., Eulalie de Mérida et de Barcelone (les Saintes), [w:] Dictionnaire d'archeologie chretienne et de liturgie, t. 5, part 1, éd. F. Cabrol, H. Leclercq, Paris 1922, kol. 705-732. 
Longosz S., Niektóre aspekty teologii męczeństwa $w$ literaturze wczesnochrześcijańskiej, „Tarnowskie Studia Teologiczne” 7 (1979), s. 49-73.

Marchot P., Les principaux traits morphologiques du wallon pré-littéraire ou préhistorique (50o-80o), „Zeitschrift für französische Sprache und Literatur” 41 (1913), s. 233-256.

Marchot P., Sur le dialecte de l'Eulalie, „Zeitschrift für romanische Philologie” 20 (1896), s. 510-514.

Marej A., Evlaliâ Merisdkaâ (Eulalia Emeritensis), sv., [w:] Katoličeskaâ enciklopediâ, t. 1, Moskva 2002, kol. 1755.

Męczennicy w świecie późnego antyku, red. B. Iwaszkiewicz-Wronikowska, D. Próchniak, Lublin 2004.

Michalski M., Antologia literatury patrystycznej, t. 1, Warszawa 1975.

Misztal H., Męczeństwo - najwyższa forma miłości - w orzecznictwie Kościoła, [w:] In Christo Redemptore. Księga pamiątkowa ku czci Księdza Profesora Jerzego Misiurka, red. J. Popławski, Lublin 2001, s. 219-237.

Moretus H., Les deux Eulalies, „Revue des questions” 117 (1911), s. 85-111.

Negri A. F., Sotomayor M., Eulalia, santa, martire in Spagna, [w:] Bibliotheca Sanctorum, t. 5, a cura di F. Caraffa, Roma 1964, kol. 208.

Nicholson G. G., Le passage controversé de la „Cantilène de sainte Eulalie”, [w:] Recherches philologiques romanes, Paris 1921, s. 242-245.

Oesterreicher-Mollwo M., Leksykon symboli „Herdera”, Warszawa 1992.

Orr J., Sur un vers de l'Eulalie, [w:] Essais d'étymologie et de philologie françaises, Paris 1963, s. 165-172.

Ortiz de Urbina I., Eulalia, santa, martire, [w:] Enciclopedia cattolica, vol. 5, a cura di P. Paschini, Città del Vaticano 1950, kol. 806.

Pieszczoch Sz., Wprowadzenie w studium Ojców Kościoła, Poznań-Warszawa-Lublin 1964.

Porteau P., La „Cantilène de sainte Eulalie” serait - elle un poéme strophique?, „Revue de linguistique romane" 9 (1933), s. 152-165.

Porter L. C., The „Cantilène de sainte Eulalie”. Phonology and Graphemics. „Studies in Philology" 47 (1960), s. 587-596.

Ptaśnik J., Kultura wieków średnich. Życie religijne i społeczne, Warszawa 1959.

Rauschen G., Zarys patrologii. Pisma Ojców Kościoła i nauka w nich zawarta, PoznańWarszawa-Wilno-Lublin 1929.

Réau L., Iconographie de l'art chrétien, t. 3, Iconographie des Saints, part 1, Paris 1958.

Recueil d'anciens textes bas-latins provençaux et français, éd. P. Meyer, Paris 1874, s. 194-195.

Sarnowska-Temeriusz R., Zarys dziejów poetyki (od starożytności do końca XVII w.), Warszawa 1985 .

Saxer V., Eulalia di Barcellona, [w:] Dizionario patristico e di antichità Cristiani, vol. 1, a cura di A. Di Berardino, Roma 1983, kol. 1279. 
Saxer V., Eulalia di Mérida, [w:] Dizionario patristico e di antichità cristiane, vol. 1, a cura di A. Di Berardino, Roma 1983, kol. 128 o.

Schauber V., Schindler H. M., Ilustrowany leksykon świętych, Kielce 2002.

Seeböck Ph., Kleine illustrirte Heiligen-Legende, Einsiedeln 1886.

Simon M., Cywilizacja wczesnego chrześcijaństwa I-IV w., Warszawa 1981.

Słownik wyrazów obcych, Warszawa 1991.

Smith A. J., Life of st. Agnes, Virgin and Martyr, Charleston 2008.

Sotomayor M. y Muro, La Iglesia en la España Romana, [w:] Historia de la Iglesia en España, t. 1, dirigida por R. Garcia-Villoslada, Madrid 1979, s. 180, 280.

Stafford M., Wera D., An illustrated dictionary of ornament, Hampshire 1974.

Starowieyski M., Męczeństwo, [w:] Męczennicy, red. E. Wipszycka, M. Starowieyski, Kraków 1991, s. 84-142.

Swoboda A., Nauka o świętym dziewictwie w pismach św. Augustyna, „Poznańskie Studia Teologiczne" 20 (2006), s. 99-115.

Verrier P., Le vers français. Formes primtives, développement, diffusion, t. 2, Paris 1932, s. $98-118$.

Waddell H., Wandering Scholars, Londres-Constable 1927.

Wenancjusz Fortunatus (Venantius Honorius Clementianus Fortunatus), [w:] Słownik wczesnochrześcijańskiego piśmiennictwa, red. J. M. Szymusiak, M. Starowieyski, Poznań 1971, s. 288-289.

Wolf F., Über die Lais, Sequenzen und Leiche. Ein Beitrag zur Geschichte der rythmischen Formen und Singweisen der Volkslieder und der volksmässigen Kirchen - und Kunstlieder im Mittelalter, Leipzig 1841.

Zumothor P., Langue et techniques poétiques á l'époque romane, Paris 1963. 